\title{
EDITORIAL
}

\section{DENTAL AMALGAM : WHAT IS THE FUTURE? MUST WE CONTINUE TEACHING AMALGAM?}

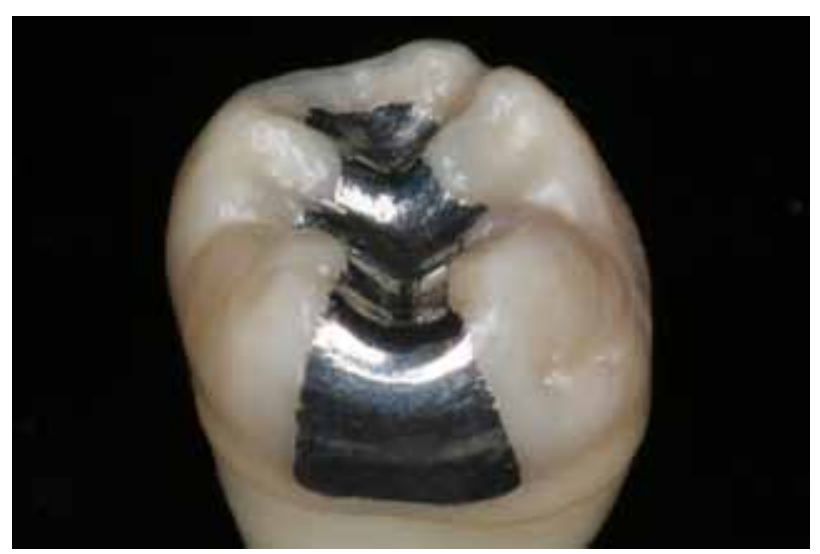

Dental amalgam restoration

Photo courtesy Prof . Carlos Rocha Gomes Torres

What is its future of Dental Amalgam? Should we keep teaching dental amalgam at Dental Schools?

The eradication of Dental Amalgam subject in some Brazilian Universities and the environmental defense activity groups created a controversial discussion within the University community.

Issues related to dental amalgam use and teaching were raised in two major events: a Symposium held at USP in September 2014, coordinated by Professors Leonardo Eloy Rodrigues Filho and Míriam Lacalle Turbino; and a Symposium held in January 2015 during the XXI Meeting of the Brazilian Group of Operative Dentistry Professors (GBPD), coordinated by Prof. Camillo Anauatte Netto, activated by Prof. Maria Fidela de Lima Navarro, and lectured by Professors Katia Dias Cervantes and Sergio Vieira.

BDS brings to you readers, with great satisfaction, the results of discussions and decisions on the dental amalgam issue, in editorials written by the coordinators of those symposia.

Scientific and educational concerns and the clinical applicability od Dental Amalgam, associated with the socio-economic condition of the country, launched the idea of sharing these important decisions.

We feel privileged to participate in this historic moment for science and education in Brazil.

Sincerely,

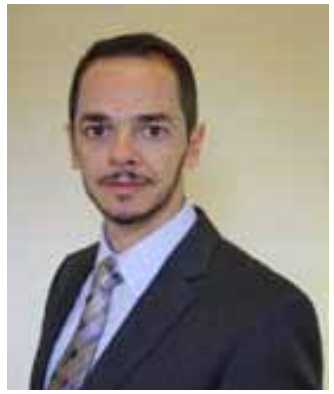

Associate Professor Sérgio Eduardo de Paiva Gonçalves Editor-in-Chief 


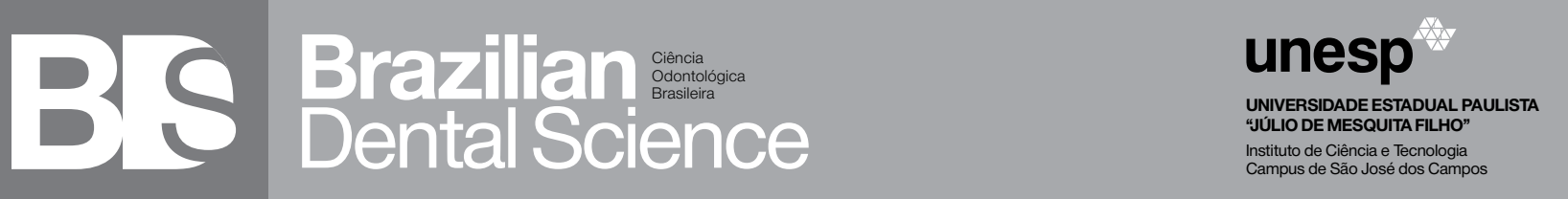

\section{EDITORIAL}

\section{DENTAL AMALGAM - WHAT IS THE FUTURE OF EDUCATION?}

Preventive actions, with consequent reduction of caries lesions, combined with improvements in composite resins, which has great appeal to be an aesthetic material, have significantly reduced the demand for dental amalgam. Accordingly, it also corroborates the fear about the possible effects of mercury, for both professionals and patients and the environment.

More recently, due to the Minamata Convention, a protocol was formulated to reduce, control and even eliminate mercury-containing products. However, there is no deadline for dental amalgam replacement, since it depends on the development of new materials.

As a consequence of this scenario, in October 2014, a symposium was held in FOUSP whose theme is the title of this editorial. Dental school professors from all over Brazil were present, as well as professionals of the public and private area and also representatives of professional associations. In the occasion, it was reaffirmed that there is still no restorative material capable of fully replace amalgam for its clinical performance qualities, greater longevity and cost significantly lower than composite resins.

Thus, by having unique properties, with marginal self-sealing, the amalgam continues to have an important indication for oral health promotion.

On the other hand, to prevent any harmful consequence for the use of mercury, should be choose the pre-dosed capsules material, use filters, protective equipment and the wastes should be stored in tightly sealed containers containing aqueous sulfur solution to sending for recycling.
In conclusion, the dental amalgam should continue as undergraduate teaching content and the educational institutions and dental professional associations should join efforts to find alternatives for the management of wastes.
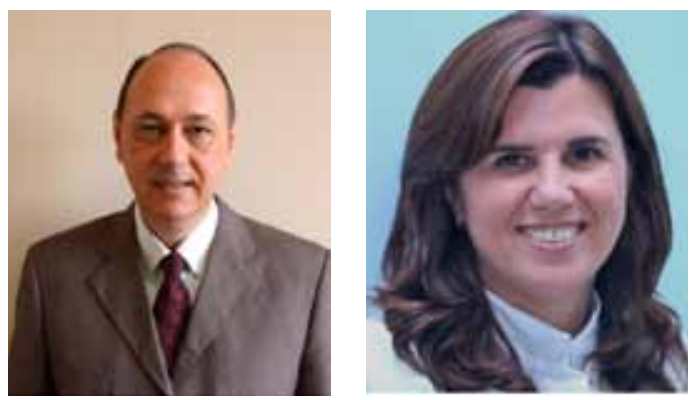

Prof. Leonardo Eloy Rodrigues Filho Prof ${ }^{\text {a }}$ Míriam Lacalle Turbino

Symposium organizers Dental amalgam - What is the future of education? FO/USO 


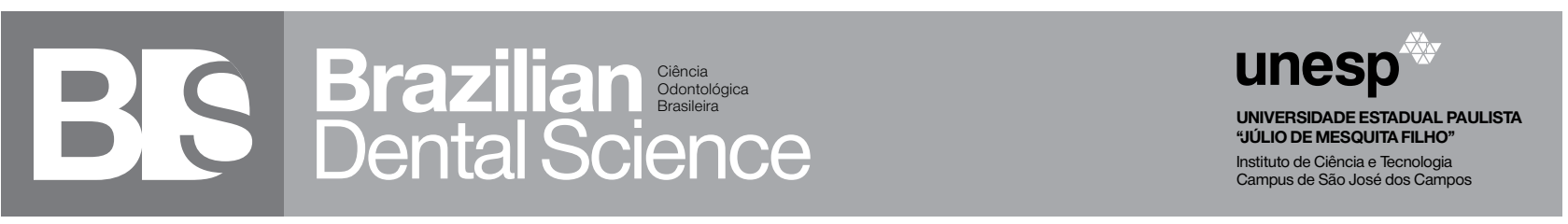

\section{EDITORIAL}

\section{MUST WE CONTINUE TEACHING DENTAL AMALGAM ?}

During the XXI Meeting of the Brazilian Group of Operative Dentistry Professors, held in Belém, PA from 14 to 17 January 2015, took place the Symposium: Should we continue teaching amalgam? Professors Katia Regina HC Dias, FO UFRJ and Sergio Roberto Vieira, PUCPR made presentations on the subject and the Professor Maria Fidela de Lima Navarro was activating the symposium.

In summary the speakers reported:

In 1956 one of the ten greatest tragedies of humanity, called "Minamata disaster" was announced: the criminal eviction for almost 30 years of 27 tons of $\mathrm{Hg}$ in the Bay of Minamata, Japan, from a plastic industry caused the death of 900 people and serious injuries to more than 2200. Since then a worldwide movement to ban the use of mercury in the world started.

In October 10, 2013, in Japan, representatives from more than 140 countries signed the Minamata Convention, which states: By 2020 - elimination of $\mathrm{Hg}$ in various materials (eg soaps, thermometers, blood pressure gauges, fluorescent lamps).

Phase down - amalgam restorations in the world. The amalgam fillings were not affected by the ban, however, the treaty suggests some provisions for the phase down of use of this material without requiring prohibitive measures or term of banishment.

The International Association for Dental Research (IADR), the World Health Organization (WHO), the World Dental Federation (FDI) and dental materials-producing companies contributed to the negotiations related to dental amalgam, suggesting greater attention to prevention and promotion of dental health, increased research and development of alternative materials and best amalgam waste management techniques.
The Study Group on the Rational Use of Dental Amalgam FO UFRJ conducted a survey within 253 dental specialists in various regions of Brazil and found that $94 \%$ of the restorations made in dental services or clinics, where these professionals work, are composite resins, $4 \%$ are glass ionomer cements and $2 \%$ are amalgams.

Professors of the PUCPR conducted an informal survey of public services and found that about 56\% of the restorations made were amalgams. These professors also reported that there is demand for training active dentists in public services to perform amalgam fillings.

These observations show that in private practices and in university clinics the use of amalgam restorations has already decreased, while in the public services there is still a strong demand for its use and that professionals are not properly qualified to perform this function well.

At the end of the event, after extensive discussions on the subject, the participants considered that there is still great demand for amalgam fillings, that with proper manipulation of the material health adverse effects do not occur and that the restoration technique with amalgam assists in the development of skills needed for the dental practice. Put to a vote, the recommendation to continue teaching amalgam in Brazilian Universities was approved unanimously.
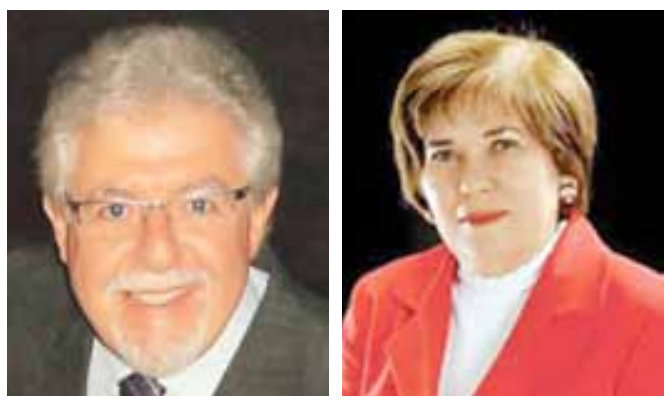

Prof. Camillo Anauate Netto

Prof ${ }^{a}$ Maria Fidela de Lima Navarro

Members of the organizing committee of the XXI Meeting of the Brazilian Group of Operative Dentistry Professors 


\section{EDITORIAL}

\section{AMÁLGAMA DENTAL: QUAL O FUTURO? DEVEMOS CONTINUAR ENSINANDO AMÁLGAMA?}

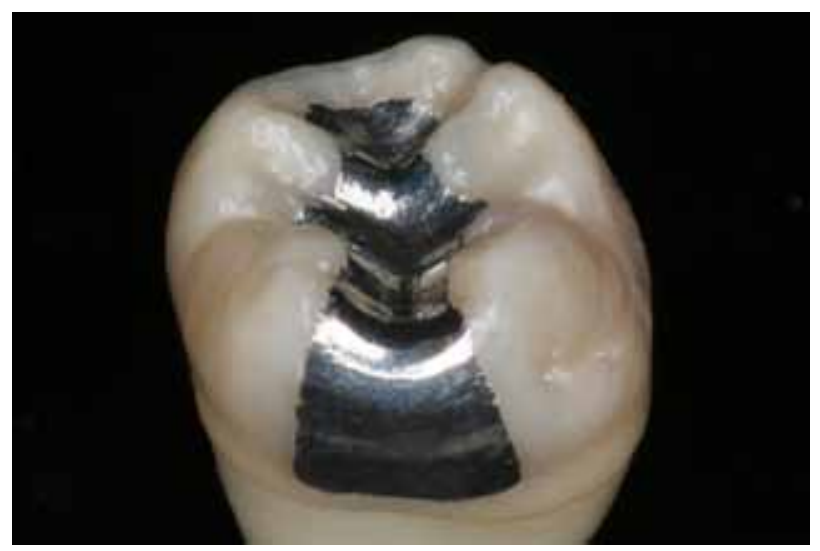

Restauração em amálgama dental

Foto cedida pelo Prof. Carlos Rocha Gomes Torres

A erradicação do ensino do Amálgama Dental por algumas Universidades Brasileiras e a ação de grupos de defesa do meio ambiente, criaram uma polêmica discussão na comunidade Universitária.

As questões relacionadas à utilização e ao ensino do amálgama dental foram levantadas em dois eventos de grande importância: o simpósio realizado na USP, sob a coordenação dos professores Leonardo Eloy Rodrigues Filho e Míriam Lacalle Turbino, em setembro de 2014; e o simpósio realizado durante o XXI Encontro do Grupo Brasileiro de Professores de Dentística (GBPD), em janeiro de 2015, sob a presidência do Prof. Camillo Anauate Netto e ativação da prof. Maria Fidela de Lima Navarro e ministrações dos professores Kátia Cervantes Dias e Sérgio Vieira.

A BDS traz a você leitor, com imensa satisfação, o balanço das discussões e decisões sobre a questão do amálgama dental discutidas nos simpósios, em editoriais escritos pelos coordenadores dos eventos.
As questões científicas, de ensino e de aplicabilidade clínica, frente à real condição sócio-econômica do pais, impulsionaram a idéia de compartilhar com toda a comunidade essas importantes decisões.

Nos sentimos privilegiados em poder participar desse momento histórico pela ciência e pelo ensino brasileiro.

Saudações,

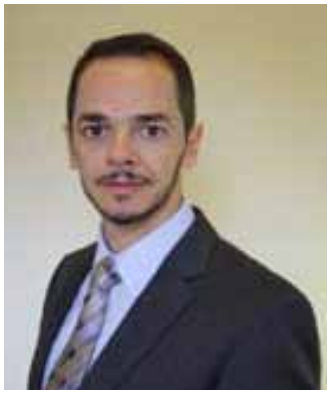

Associate Professor

Sérgio Eduardo de Paiva Gonçalves Editor Chefe 


\section{EDITORIAL}

\section{AMÁLGAMA DENTAL - QUAL O FUTURO DO ENSINO?}

As ações de prevenção, com consequente diminuição das lesões de cárie, aliadas às melhorias das resinas compostas, que tem o grande apelo de ser um material estético, têm diminuído significativamente a demanda pelo amálgama dental. Nesse sentido, também corrobora o temor com os possíveis efeitos de mercúrio, tanto para pacientes e profissionais como para o meio ambiente.

Mais recentemente, em função da convenção de Minamata, foi formulado um protocolo para a redução, controle e até eliminação de produtos que contenham mercúrio. Contudo, para o amálgama dentário não foi estabelecido prazo para sua substituição, já que depende do desenvolvimento de novos materiais.

Como consequência desse cenário, foi realizado em outubro de 2014, na FOUSP, um simpósio cujo tema é o título deste editorial. Compareceram professores de Faculdades de Odontologia de todo o Brasil, bem como profissionais da área pública e privada além de representantes de entidades de classe. Na ocasião foi reafirmado que não existe ainda um material restaurador capaz de substituir totalmente o amálgama, por suas qualidades de desempenho clínico, com maior longevidade e custo significativamente menor que o das resinas compostas.

Assim, por ter propriedades inigualáveis, com o autovedamento marginal, o amálgama continua a ter indicação importante para a promoção da saúde bucal.

Por outro lado, para prevenir qualquer consequência danosa pela utilização do mercúrio, deve-se escolher o material pré-dosado em cápsulas, usar filtros, equipamentos de proteção e os resíduos devem ser armazenados em potes bem vedados, contendo solução aquosa de enxofre para envio para reciclagem.

Concluiu-se que, o amálgama deverá continuar como conteúdo de ensino de graduação, e que as instituições de ensino e de classe de odontologia devem somar esforços para encontrar alternativas para o gerenciamento dos resíduos.
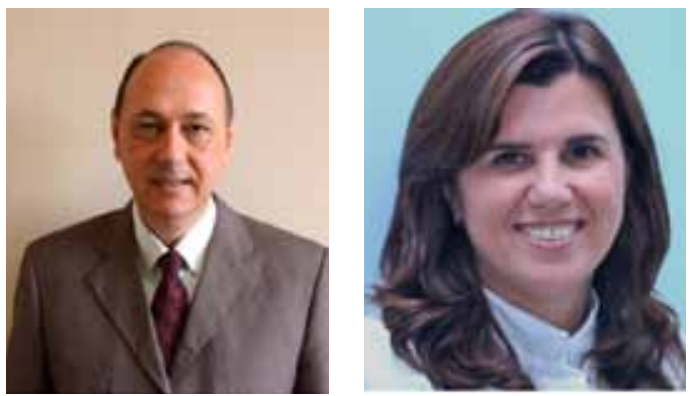

Prof. Leonardo Eloy Rodrigues Filho Prof ${ }^{a}$ Míriam Lacalle Turbino

Organizadores do Simpósio Amálgama Dental: qual o futuro no ensino? FO - USP $-2014$. 


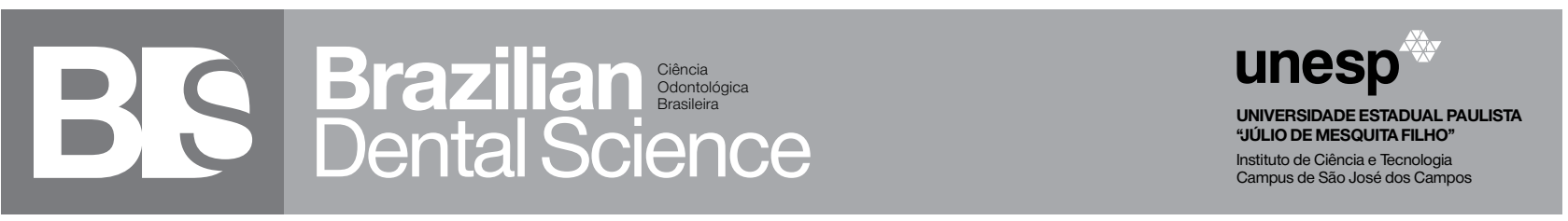

\section{EDITORIAL}

\section{DEVEMOS CONTINUAR ENSINANDO AMÁLGAMA DENTAL ?}

Durante o XXI Encontro do Grupo Brasileiro de Professores de Dentística, realizado em Belém, PA, de 14 a 17 de janeiro de 2015, ocorreu o Simpósio: Devemos continuar ensinando amálgama? Os professores Katia Regina H C Dias, da FO UFRJ e Sérgio Roberto Vieira, da PUCPR fizeram apresentações sobre o tema e a professora Maria Fidela de Lima Navarro foi ativadora do simpósio.

Em resumo os palestrantes relataram:

Em 1956 foi divulgada uma das dez maiores tragédias da humanidade, chamada de "Desastre de Minamata": o despejo criminoso durante quase 30 anos, por uma indústria de plástico de 27 toneladas de $\mathrm{Hg}$ na Baia de Minamata, no Japão, ocasionou a morte de 900 pessoas e lesões graves em mais de 2200. A partir de então começou um movimento mundial para banir o uso do mercúrio no mundo.

Em outubro de 2013, no Japão, os representantes de mais de 140 países assinaram a Convenção de Minamata que estabelece: Até 2020 - eliminação do $\mathrm{Hg}$ em vários materiais (ex. sabonetes, termômetros, medidores de pressão sanguínea, lâmpadas fluorescentes

Diminuição gradual - restaurações de amálgama no mundo. As restaurações de amálgama não foram atingidas pela proibição, no entanto, o tratado sugere algumas disposições relativas à diminuição gradual de uso desse material, sem exigir medidas proibitivas ou prazo de banimento.

A International Association for Dental Research (IADR), a Organização Mundial da Saúde (OMS), a World Dental Federation (FDI) e as empresas produtoras de materiais dentários contribuíram para as negociações relacionadas ao amálgama dental, sugerindo maior atenção à prevenção e promoção da saúde dental, aumento da investigação e desenvolvimento de materiais alternativos e melhores técnicas de gestão de resíduos de amálgama.

O Grupo de Estudo sobre o Uso Racional do Amálgama Dental da FO UFRJ realizou uma pesquisa com 253 especialistas em Dentística das diversas regiões brasileiras e constatou que 94\% das restaurações realizadas nos serviços ou clínicas odontológicas onde os profissionais atuam são de resina, 4\% são de CIV e $2 \%$ são de amálgama.

Docentes da PUCPR realizaram um levantamento informal em serviços públicos e observaram que cerca de $56 \%$ das restaurações realizadas eram de amálgama. Esses docentes relataram também que está havendo demanda para ministração de treinamento para os dentistas atuantes na rede pública para realização de restaurações de amálgama.

Essas observações mostram que nos consultórios particulares e nas clínicas das universidades o uso do amálgama já está bem diminuído, enquanto nos serviços públicos ainda há uma forte demanda para seu uso e que os profissionais não estão sendo qualificados adequadamente para bem desempenhar essa função.

Ao final do evento, após ampla discussão sobre o tema e tendo em vista que: ainda há muita demanda para as restaurações de amálgama; com os cuidados adequados, não ocorrem efeitos adversos à saúde e que a técnica de restauração com amálgama auxilia no desenvolvimento de habilidades necessárias para a prática odontológica, colocada em votação, a recomendação de manter o Ensino do Amálgama nas Universidades Brasileiras foi aprovada por unanimidade.

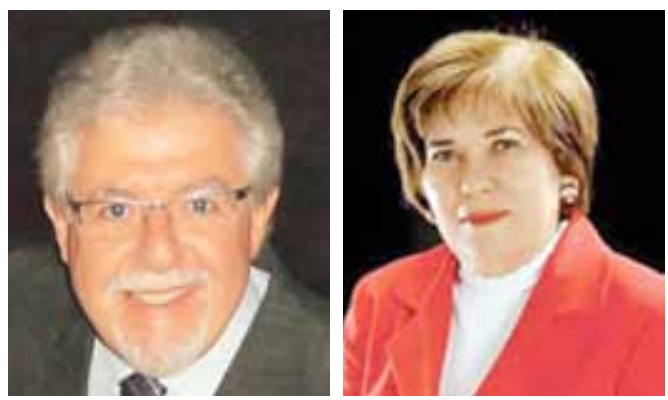

Prof. Camillo Anauate Netto

Prof $^{a}$ Maria Fidela de Lima Navarro

Membros da comissão organizadora do XXI Encontro do Grupo Brasileiro de Professores de Dentística 